\section{Routines, Generative Systems Analyzed as a Function Based on Time and Innovation}

\author{
Júlio César da Costa Júnior ${ }^{1}$ \\ julioccostajr@gmail.com | (10) 0000-0001-8021-4989 \\ Marcos André Mendes Primo ${ }^{1}$ \\ marcos.primo@ufpe.br| (D) 0000-0001-8126-9252 \\ Taciana de Barros Jerônimo ${ }^{1}$ \\ taciana.barros@gmail.com | (D) 0000-0003-1643-3030
}

\begin{abstract}
This study aims to propose a model to study organizational routines as a generative system based on time and innovation. Routines are intrinsically related to resources orchestration processes, learning, know-how accumulation and organizational expertise. Over time, combined with innovations, inprocess, or via technological artifacts, routines may contribute to diversifying the portfolio of outputs able to add value to a company result. The study follows a qualitative approach, with an applied nature, and was made through multiple case studies. Data collection was through semi-structured interviews and was beaconed by protocol subject to peers validation. The main contribution is the model which is proposed to understand routines as a generative system able to diversify the outputs or organizational actions enhancing the results arisen from innovations. Results have confirmed the relation between routines and resources orchestrations process, incorporation and development of innovations, and organizational learning.
\end{abstract}

\section{KEYWORDS}

Routines, Resources orchestration, Innovation
${ }^{1}$ Universidade Federal de Pernambuco, UFPE, Recife, PE, Brasil

Received: 05/04/2020.

Revised: 10/23/2020.

Accepted: 12/21/2020.

Published Online: 08/16/2021.

DOI: http://dx.doi.org/10.15728/bbr.2021.18.5.2 


\section{INTRODUCTION}

Routines are the building blocks on which a company is built: they enable it to fulfill its role in

society and direct its competitive behavior (Becker, Lazaric, Nelson, \& Winter, 2005; Feldman, Pentland, D'Adderio, \& Lazaric, 2016). Routines role are fundamental to the daily operation of organizational operations; creation process and knowledge and new abilities accumulation; learning; variance and selective retention of new action patterns (Pentland, Feldman, Becker, \& Liu, 2012; Deslée \& Ammar, 2016).

The combination of different routines operating cohesively is the base for the formation of capabilities and represents what a company can do with a set of resources (Grant, 1991; Wang \& Wang, 2017). As the foundation to capabilities, routines allow analyzing, on a micro-level, how the resource management and development process from a focus on the situated action of the agents involved in its performance (Pentland et al., 2012; Feldman et al., 2016). Likewise, through routine exercises, an organization accumulates the necessary know-how and expertise to develop the current assets base, or create new ones, which are able to aggregate value to problemsolving (Grant, 1991; Peteraf, Stefano, \& Verona, 2013).

This is directly related to the resources orchestration process integral to the strategic entrepreneurship approach (Sirmon, Hitt, Ireland \& Gilbert, 2011). Based on the theoretical pillar of a Resource-Based View, the focus of orchestration is on resources management and consecution of a strategy aimed to explore current advantages, exploitation; and in prospecting new possibilities of adding value to the results of business actions, and exploration (Hitt, Ireland, Sirmon, \& Trahms, 2011; Wu, Melnyk, \& Swink, 2012).

This study is based on the hypothesis that routines, on a micro-level of analysis, are intrinsically related to the resource orchestration process, organizational learning, and knowledge accumulation and, thus, contribute to the innovation process (Becker et al., 2005; Bredillet, Tywoniak, \& Tootoonchy, 2018; Desleé \& Ammar, 2016; Boe-Lillegraven, 2019; Kiwan \& Lazaric, 2019; Sele \& Grand, 2016). As generative systems, routines should be considered as an organizational processes that transform different inputs into outputs (Pentland \& Feldman, 2005; Feldman et al., 2019). Thus, small variations on the executed action patterns may contribute to the diversification of the organization portfolio (Pentland et al., 2012; Kremser, Pentland, \& Brunswicker, 2019; Feldman et al., 2019).

Likewise, over time, considering its dimensions of continuous events flow, Kairos, and calendar time, Chronos (Araujo \& Easton, 2012), routines also evolve in complexity. During the events, combined with innovations and other resources acquired by the company, existing routines may extrapolate their capacity and generate a bigger output portfolio that adds value to the result of business activity (Pentland et al., 2012; Feldman et al., 2016). If the resources and outputs of a company are two sides of the same coin (Wernefelt, 1984, p.171), the effective evolution of routines and assets base are able to deliver outputs of greater added value.

Thus, the goal of this study is to propose a model to represent the effect of routines in the diversification of outputs of the organizational process on an aggregated perspective: considering generative systems, routines are represented as a function based on time and innovation. 


\section{ROUTINES: DYNAMIC BALANCE, CHANGE, AND INNOVATION}

Routines are recognizable and repetitive patterns of interdependent actions and decisions through which resources are applied to the processes of an organization (Feldman \& Pentland, 2003, p.96; Bredillet et al., 2018). Since they deals with asset allocation and coordination, analysis of routines allows for the identification and development of great alternatives to enhance the current resource base and abilities of a company, or even recombine them to create other elements able to increase performance (Grant, 1991; Peteraf et al., 2013).

As dynamic processes, the analysis of the interaction between components allows for an understanding of how routines enable dynamic balance and organizational change (Bredillet et al., 2018, p.30). Ostensive component refers to the logical scheme for the performance of a routine on an abstract level, which guides the agents' actions and is influenced by the general understanding of how an organization operates (Feldman \& Pentland, 2003, p.797; Pentland et al., 2012). The performative element refers, on a concrete level, to specific actions executed by individual e actors when engaged in what they think is a routine (Pentland \& Feldman, 2005, p.796; Bredillet et al., 2018). Artifacts are formal rules, operational procedures, information, and communication technologies and equipment (Pentland \& Feldman, 2005, p.797; Pentland et al., 2012).

Through the interaction and attrition between these elements, new action patterns are created that remain in a dormant state and intensify the organizational learning process (Feldman et al., 2016; Bredillet et al., 2018). The historical component or the trajectory of a company has a strong influence on the variation and selective retention processes of action patterns of a routine: each new performance depends, to a certain extent, of the previous and those more relevant performances for an organization (Pentland et al., 2012, p.1492).

However, it should be highlighted that routines are hardly ever performed just by humans: they are enacted by a group of agents (actants), including non-humans (Pentland et al., 2012, p.1486). Such finding reveals a new dimension given to the artifacts for the performance of a routine: as organizational practices, routines have an inherently material dimension on the form of artifacts that are intimately interlaced to human agency (Orlikowski, 2015). Artifacts and their properties emerge from a heterogeneous net of social and technical elements that build them (D’Adderio, 2011, pp.201-202).

This perspective, which considers the sociomateriality inherent to routines, therefore implies that there is no primacy of a specific type of actor for its performance: agency, cognition, and organizational memory are entangled in complex arrangements of people and artifacts (Pentland et al., 2012, p.1487; D’Adderio, 2008; Dittrich \& Seidl, 2018; Boe-Lillegraven, 2019).

As a unit of analysis, routines are a useful conceptual tool to understand the dynamics of organizing processes at different levels (Bredillet et al., 2018). The dynamics of routines on a macro level emerges from the relations between specific actions and action patterns that occur on a micro-level (Pentland et al., 2012, p.1484). In other words, routines link micro and macro perspectives of organizational action in a way that could be considered preceding to capabilities, dynamic or operational (Bredillet et al., 2018, p.30; Pentland et al., 2012, p.1488). This finding reinforces the interrelation between routine perspective with organizational capabilities evidenced in a substantial part of correlated literature (Grant, 1991; Teece, Pisano, \& Shuen, 1997; Eisenhardt \& Martin, 2000; Peteraf et al., 2013; Wang \& Wang, 2017). 
The performance of a company's routines enables the development of specialized knowledge, know-how, and expertise necessary to elevate its competitiveness. Thisaccumulation may lead to change and incremental innovations (Becker et al., 2005; Appiah \& Sarpong, 2015; Ranucci \& Souder, 2015; Kremser et al., 2019). This stock of singular abilities leads to the development of essential competencies, which refer to the collective knowledge developed in the company, especially about operational capabilities and technologies for outputs production, which add value to the result (Prahalad \& Hamel, 1990; Shin, Han, Marhold, \& Kang, 2017). Such competencies define the fundamental business of a company, and become distinct, as to ensure that the company maintains a competitive advantage and access to a greater variety of buisiness (Prahalad \& Hamel, 1990; Matzler, Bailom, Anschober, \& Richardson, 2010).

Gradually, the combination of essential competencies with other resources, technologies, and new dormant action patterns becomes the base for the evolution of routines and, consequently, of the capabilities of an organization (Becker et al., 2005; Matzler et al., 2010; Pentland et al., 2012; Bredillet et al., 2018).

As generative systems (Feldman et al., 2016), routines, on a micro-level analysis, enable an organization to diversify its competences, processes, and outputs portfolio, which, on a macro perspective, will have implications for the development of its resources and capabilities base (Pentland et al., 2012; Bredillet et al., 2018).

However, it should be highlighted that these are not only operational changes. This process influences management behavior on an entrepreneurship bias and that may lead the organizations to strategic reorientations that optimize performance from the exploitation of new routines and developed capabilities (Appiah \& Sarpong, 2015; Ranucci \& Souder, 2015; Deslée \& Ammar, 2016). This argument will be developed later

\section{ROUTINES AND STRATEGIC ENTREPRENEURSHIP: RESOURCES ORCHESTRATION AND DEVELOPMENT}

The perspective of routines asfoundational for capabilities, as well as intrinsically related to resources management and organizational learning (Pentland et al., 2012; Feldman et al., 2016; Wang \& Wang, 2017) dialogues with the perspective of strategic entrepreneurship whose core refers to actions taken to explore current advantages and, simultaneously, explore new opportunities that support the ability of a company to add value to its activities (Hitt et al., 2011, p.57). Besides considering the role of available resource management through developed capabilities (Sirmon et al., 2011), the approach incorporates the relevance of environment, innovation, micro-processes, decisions of the involved agents and enables a multilevel analysis of the organizational action (Kantur, 2016; Omotosho \& Anyigba, 2019).

As the strategic dimension of the construct emphasizes the creation and sustenance of competitive advantage by exploitation of the current resource base or inputs, exploitation; the entrepreneurship dimension focus on identifying and exploring new opportunities through the development of innovations from the organizational learning, exploration (Hitt et al., 2011; Wu et al., 2012). In this sense, learning and the accumulation of know-how enabled by routines performance becomes fundamental for the upgrade of the organizational processes in the search of adding value to its outputs (Ranucci \& Souder, 2015; Deslée \& Ammar, 2016; Kantur, 2016). 
BBR

18

494

Fundamental to the strategic entrepreneurship model is the perspective of resources orchestration, which is based on theoretical assumptions of Resource-Based View (Barney \& Arikan, 2017; Sirmon et al., 2011). From the premise of an organization as a resource package (Penrose, 1959), resources orchestration worries with actions taken by the leaders to facilitate the efforts related to the effective application of assets on the achievement of a strategy (Hitt et al., 2011, p.64). However, it should be highlighted that this does not imply an underestimate or ignore the environment: it is the synchronization between resources management and environmental opportunities that enhances the results (Penrose, 1959; Sirmon et al., 2011; Omotosho \& Anyigba, 2019).

Resources orchestration refers to structuring, bundling, leveraging, and value creation (Hitt et al., 2011). Returning to the Resource-Based View (RBV), resources structuring involves: acquisition processes and resource stock formation (Wernefelt, 2011); internal assets development and its combination with those acquired on strategic factors market (Maritan \& Peteraf, 2011); creation of singular assets portfolios through the ability to combine them in a superior amalgam to provide advantages (Sirmon et al., 2011).

This last aspect, specifically, is related to the bundling: grouping resources demands specific knowledge regarding its potential for application and future development, whose exercise also implies on a context of perennial learning through the routines that articulate them (Itame \& Roehl, 1987; Hitt et al., 2011, p.64). However, although the acquisition and internal development of assets can provide advantages associated with mass efficiency and interconnection of resources (Dierickx \& Cool, 1989; Wernefelt, 2011; Maritan \& Peteraf, 2011), it is the leveraging of resources, that refers to its application, which moves the company from a potential situation to the realization of value (Sirmon et al., 2011).

Underlying resources leveraging, again, is the assumption of synchronism between this process and its environment (Omotosho \& Anyigba, 2019). Essentially, the growth of a company is limited by the productive opportunities that exist according to its resources and the management infrastructure to coordinate them (Penrose, 1959; Barney \& Arikan, 2017). Amplifying the resources' portfolio and capabilities implies, in entrepreneurial actions, strategic dimensions that allow for the simultaneous exploration of current resources, and their development over a longer time period, as seen in a dynamic resource fit (Itami \& Roehl, 1987, p.125; Sirmon et al., 2011). In other words, regarding the current strategy, a company must be able to develop the necessary elements to ensure a competitive advantage in the future (Grant, 1991, p.132; Itami \& Roehl, 1987; Omotosho \& Anyigba, 2019).

Finally, successfully exploring an opportunity and creating value from a group of resources is an invitation to imitation (Hitt et al., 2011, p.66); thus, protecting the sources of advantages of business is urgent to guaranteeing its sustenance (Rumelt, 1984). Though formal mechanisms, such as patent protection, contracts, and others, are highlighted in researche (Hitt et al., 2011), the causal ambiguity,imperfect transference capacity, and impossibility of substitution, typical attributes of resources able to provide a competitive advantage by RBV theoretical lenses, still arise as relevant elements (Rumelt, 1984; Grant, 1991; Rashidirad, Soltani, Salimian, \& Liao, 2015).

Through a unique path of learning accumulated by the performance of their routines, a company may develop singular abilities and expertise in terms of the orchestration of its portfolio of resources (Feldman et al., 2016; Bredillet et al., 2018; Ranucci \& Souder, 2015). This path dependence perspective allows for comprehending how elements of the organization's history may influence the processes of variation and selective retention of new action patterns that emerge through routines (Pentland et al., 2012) and, thus, contribute to making obstacles to the imitation of the elements that leverage its performance (Grant, 1991; Rashidirad et al., 2015). 
An integral part of capabilities, and responsible, in a micro perspective, for resources articulation and development, routines are related to strategic entrepreneurship and enable innovation processes through accumulated tacit knowledge that remains dispersed in a wider net of singular processes in each company (Hitt et al., 2011; Pentland et al., 2012; Ranucci \& Souder, 2015; Deslée \& Ammar, 2016). This evolutive process, though gradual, is not linear: it may suffer leaps from specific events that, by propelling routine development with greater intensity, have effects of time compression. This aspect of temporality will be discussed further on.

\section{SITUATING TEMPORALITY}

To situate the dimension of the time factor on the evolution of routines and resources orchestration, it is worth highlighting the intrinsic dialectic of the temporal approach in social sciences. The Greek conception of Kairos time, which considers time as a flow of qualitatively heterogeneous events, and Chronos time, which represents the metrological, linear and patterned notion of time, illustrate this contrast between procedural and discreet emphasis about the nature of events (Araujo \& Easton, 2012, p.313).

In a similar way, the conception of temporal series $A$ and $B$ ratify the conceptions of time in a continuous flow between past, present and future events, which is series A; and time reduced to the chronology of facts as a transitive order in the relation between events, which is series $\mathrm{B}$ (Brown \& Herring, 1998, p.581).

On the case of the proposal of a dynamic resource fit (Itami \& Roehl, 1987; Sirmon et al., 2011) and the gradual evolution of routines (Feldman et al., 2016; Bredillet et al., 2018) the implicit temporal approach dialogues with the concept of time as a continuous e flow of events, which is series A or Kairos time (Araujo \& Easton, 2012). However, series A and B, Chronos and Kairos, primarily refer to how events are experienced and not necessarily to different types of time (Brown \& Herring, 1998, p.581).

Processes are analyzed as a sequential progression of events on a specific calendar period in which change is an abstraction built from the differences observed on the phenomenon (Van de Ven \& Poole, 1995, p.512; Araujo \& Easton, 2012, p.313). Therefore, overlaid to the chronological timeline, Chronos time, there are events in the flow, Kairos time, that cannot be analyzed in a purely linear way, even anchored to time points, due to the impact on the evolution of the portfolio of resources and capabilities.. The intense learning, result of these experiences, may lead to evolutive leaps in a short chronological span, causing a time compression effect.

In other words, in this analysis, the events flow time, which is Kairos, and calendar time, which is Chronos, must be considered contiguous: specific events located on the chronological line may work as levers to propel the development of the organization on a short period of time. Therefore, the rhythm of the changes is not linear and can be accelerated according to the impact of happenings.

\section{METHODOLOGICAL PROCEDURES}

This study follows a qualitative approach, with descriptive character and applied nature, aiming to provide new possibilities of theoretical articulation between the main constructs approached and building an empirical model based on the deductions arisen from the analysis of the results (Creswell \& Creswell, 2017; Flick, 2018). For the field research, the technical procedure adopted was multiple case studies since it enables a deep and exhausting investigation of an event in its real context (Yin, 2018; Lindgreen, Di Benedetto, \& Beverland, 2020; Eisenhardt, 1989). The case 
study has superior analytical potential to answering 'how' and 'why' types of questions because it allows the combination of different sources of evidence in the repertoire of an investigation (Eisenhardt \& Graebner, 2007, p. 26; Eisenhardt, 1989, p. 534). Furthermore, the option for multiple cases enables a wide exploration of the assumptions that support the research, makes viable more sophisticated theoretical elaborations, and allows the construction of more robust arguments based on a larger portfolio of empirical evidence (Eisenhardt \& Graebner, 2007, p. 27).

Data collection was through a semi-structured interview, observation, and document analysis (Flick, 2018) and was beaconed by protocol previously subject to peers face validation (Eisenhardt, 1989, p. 538; Yin, 2018). The interviewed individuals were: managers of the selected companies, due to the impact of their decisions on resources orchestration (Hitt et al., 2011); and employees on the operational level, due to their direct involvement with the operational routines of the companies (D'Adderio, 2008). It is noteworthy that the interviews with managers focused on the management of the company, and on decisions that affect the operational level regarding the use of resources; in the case of employees at the operational level, the emphasis was on the execution of routines and on how their work was affected by the managers' decisions regarding the use of resources. In other words, the interviews with the two groups had a complementary perspective and the reports of both groups were cohesive. Little divergences, such as details of the execution of a routine reported inconsistently by the managers, did not affect the development of the theoretical argument or the elaboration of the model. Some examples of these divergences are changes in the proportion of ingredients or small contingent variations in the production schedule. Altogether there were about 30 hours of interviews, electronic recording was authorized only for those donewith managers. In the case of production employees, the records were made in a field diary. Complementary aspects of the interviews are complemented in Table 1.

The observation of the non-behavioral, direct, non-participating, and systematic type, focused on mapping the investigated routines for later comparison with the reports obtained in the interviews (Creswell \& Creswell, 2017). The documentary analysis included process maps and standardized operational procedures to complement data triangulation and validity (Flick, 2018). Regarding this data source, it is highlighted that small differences were identified concerning what was observed, however, this did not affect the legitimacy of the data collected. In cases where this occurred, it was reported in the interviews that such manuals could be outdated or present small differences due to experimentation. Besides, according to theoretical constructs that support the research, routines are dynamic, and small variations in the pattern performed in each cycle would be expected (Feldman et al., 2016).

The six companies studied were selected based on predictable replication logic and comprise a non-probabilistic but intentional sample (Yin, 2018, Eisenhardt \& Graebner, 2007, p. 27; Eisenhardt, 1989). The cases were selected from a universe composed of eight companies recognized as a reference in quality and superiority in the service offered by the public in the locus of research in a national gastronomic guide of great circulation, namely "Veja Comer e Beber - Recife". According additional criterion for accessibility, the six companies that consented to participate in the study followed. Due to the access to $75 \%$ of the companies referenced in the considered guide, the research followed and the possibility of expanding the universe and the sample was preserved, if necessary. However, due to the availability and collaboration of participating companies with the entire data collection process, it was possible to obtain theoretical saturation. 
Table 1

Main interviewees profiles

\begin{tabular}{|c|c|c|}
\hline Case & Function / position & General description \\
\hline \multirow[t]{2}{*}{$\mathrm{B} 1$} & Manager & $\begin{array}{l}\text { Male, } 33 \text { years old, graduation in administration, Master } \\
\text { Business of Economics, about } 2 \text { years in the bakery business }\end{array}$ \\
\hline & $\begin{array}{l}\text { Production employees } \\
\text { ( } 2 \text { respondents) }\end{array}$ & $\begin{array}{l}\text { Males, high school, more than } 5 \text { years of experience in the } \\
\text { bakery sector }\end{array}$ \\
\hline \multirow[t]{2}{*}{$\mathrm{B} 2$} & Manager & $\begin{array}{l}\text { Male, } 53 \text { years old, graduation in administration, Finance } \\
\text { MBA, more than } 6 \text { years in the sector }\end{array}$ \\
\hline & $\begin{array}{l}\text { Production employees } \\
\text { ( } 2 \text { respondents) }\end{array}$ & $\begin{array}{l}\text { Males, high school, more than } 10 \text { years of experience in the } \\
\text { bakery sector }\end{array}$ \\
\hline \multirow[t]{2}{*}{ B3 } & Manager & $\begin{array}{l}\text { Male, } 32 \text { years old, graduation in administration, MBA in } \\
\text { Business Management, about } 10 \text { years in the sector }\end{array}$ \\
\hline & $\begin{array}{l}\text { Production employees } \\
\text { (3 respondents) }\end{array}$ & $\begin{array}{l}\text { Males, high school, more than } 20 \text { years of experience in the } \\
\text { bakery sector }\end{array}$ \\
\hline \multirow[t]{2}{*}{ B4 } & Manager & $\begin{array}{l}\text { Male, } 51 \text { years old, graduation in computing and in accounting } \\
\text { sciences, MBA in Business Management, more than } 20 \text { years in } \\
\text { the sector }\end{array}$ \\
\hline & $\begin{array}{l}\text { Production employees } \\
\text { ( } 3 \text { respondents) }\end{array}$ & $\begin{array}{l}\text { Males, high school, about } 20 \text { years of experience in the bakery } \\
\text { sector }\end{array}$ \\
\hline \multirow[t]{2}{*}{ B5 } & Manager & $\begin{array}{l}\text { Male, } 40 \text { years old, graduation in administration, about } 20 \\
\text { years in the sector }\end{array}$ \\
\hline & $\begin{array}{l}\text { Production employees } \\
\text { ( } 2 \text { respondents) }\end{array}$ & $\begin{array}{l}\text { Males, high school, more than } 10 \text { years of experience in the } \\
\text { bakery sector }\end{array}$ \\
\hline \multirow[t]{2}{*}{ B6 } & Manager & $\begin{array}{l}\text { Male, } 39 \text { years old, graduation in administration, about } 10 \\
\text { years in the sector }\end{array}$ \\
\hline & $\begin{array}{l}\text { Production employees } \\
\text { (1 respondent) }\end{array}$ & $\begin{array}{l}\text { Male, high school, about } 5 \text { years of experience in the bakery } \\
\text { sector }\end{array}$ \\
\hline
\end{tabular}

Besides ratified in gastronomic guides of great influence, the cases match other predetermined criteria about the sample population (Eisenhardt, 1989, p. 537, Lindgreen et al., 2020): about the corporate size, micro, and small businesses; branch of activity, the main activity in the production of bakery and confectionery products; and undergoing operational adjustments to suit industry trends, as highlighted in the case analysis below. This well-defined population concept is essential in case studies as it defines the general configuration of the selected entities and enables more robust inferences based on the similarities or differences found (Eisenhardt, 1989).

The methodological design of this study, along with complementary information such as the general principles of quality in the research carried out through a case study that marked this work (Eisenhardt, 1989; Eisenhardt \& Graebner, 2007; Lindgreen et al., 2020) are summarized in Figure 1.

The data assessment followed the systematic of thematic content analysis: pre-analysis, exploitation of the material, and interpretative treatment of the data (Flick, 2018; Bardin, 2016). Content analysis was chosen because it allows the study of communications and text materials to describe its meaning after interpretive treatment (Creswell \& Creswell, 2017). Thus, based on the breakdown of the material collected into categories and subcategories related to the theme it refers to, the analysis continued with interpretive treatment to provide meaning to the findings within the context of the investigation (Erlingsson \& Brysiewicz, 2017). The definition of 
analytic categories was based on the main theoretical constructs that guide the study and work as anchors to define what data would be incorporated into the analysis (Creswell \& Creswell, 2017; Erlingsson \& Brysiewicz, 2017). Thus, from a theoretical perspective, it was possible to locate the data and support the arguments presented, as well as the construction of the model. An overview of the content analysis procedure is shown in Figure 2, while the main theoretical categories that supported the analysis are shown in Table 2.

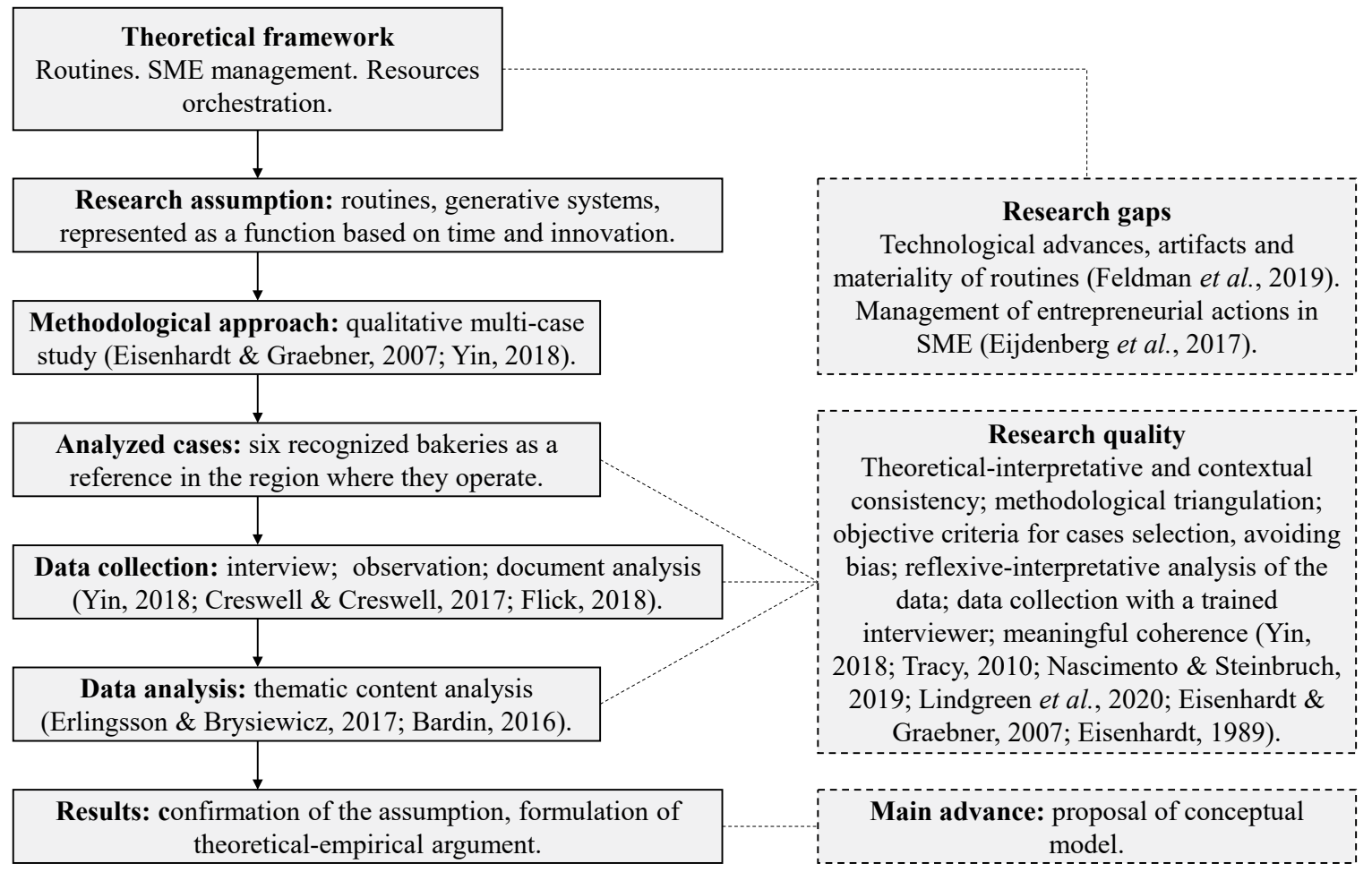

Figure 1. Methodological design.

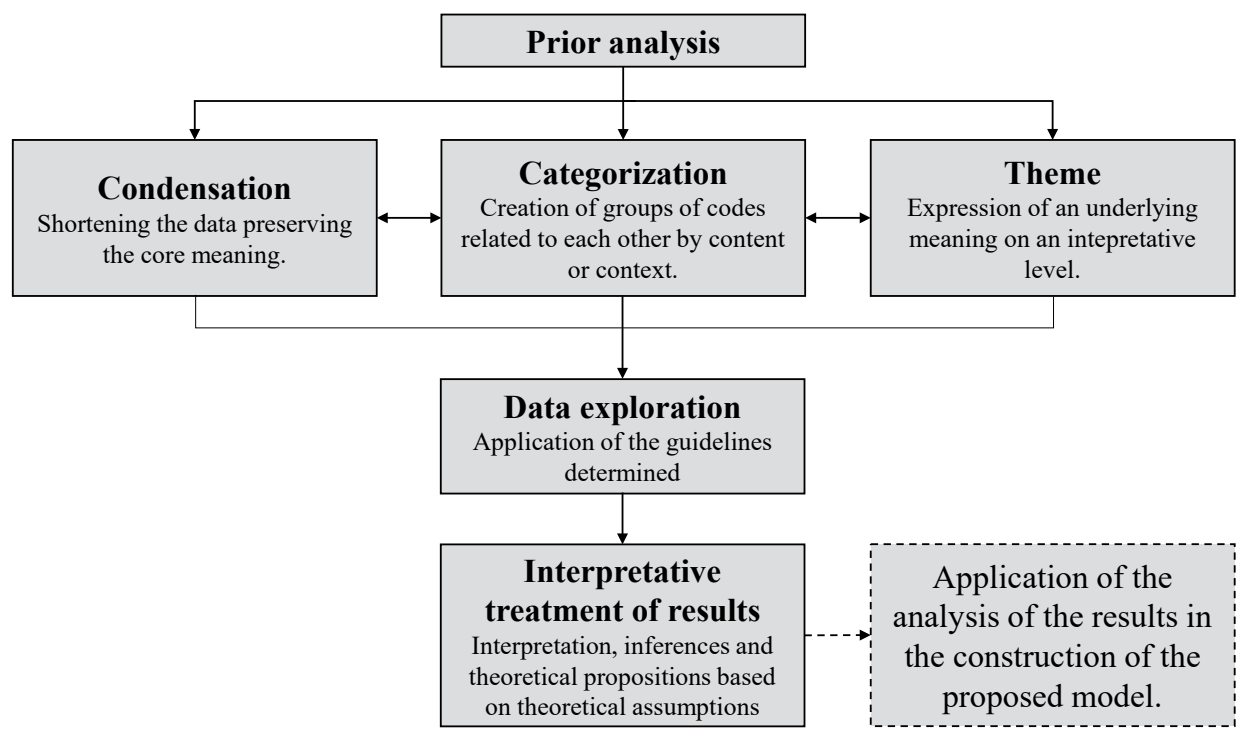

Figure 2. Content analysis flow. 
Table 2

Main theoretical categories

\begin{tabular}{|c|c|c|}
\hline Category & Subcategory & Main references \\
\hline \multirow[t]{4}{*}{ Dynamic routines } & Routine components & $\begin{array}{l}\text { Pentland \& Feldman, 2005; Feldman \& Pentland, } \\
\text { 2003; Bredillet et al., } 2018 \text {. }\end{array}$ \\
\hline & $\begin{array}{l}\text { Know-how, expertise, } \\
\text { learning }\end{array}$ & $\begin{array}{l}\text { Kiwan \& Lazaric, 2019; Feldman et al., 2016; Wang } \\
\text { \& Wang, 2017; Boe-Lillegraven, } 2019 .\end{array}$ \\
\hline & $\begin{array}{l}\text { Innovation and novelty } \\
\text { through routines }\end{array}$ & $\begin{array}{l}\text { Bredillet et al., 2018; Pentland et al., 2012; Van Mierlo } \\
\text { et al., } 2019 .\end{array}$ \\
\hline & $\begin{array}{l}\text { Technology and } \\
\text { sociomateriality }\end{array}$ & $\begin{array}{l}\text { Feldman et al., 2019; Kiwan \& Lazaric, 2019; } \\
\text { D’Adderio, 2011; Dittrich \& Seidl, } 2018 .\end{array}$ \\
\hline \multirow[t]{2}{*}{ Small enterprises } & $\begin{array}{l}\text { Limitations and } \\
\text { restrictions }\end{array}$ & $\begin{array}{l}\text { Wrona \& Ladwig, 2015; Kellinher \& Reinl, 2009; } \\
\text { Parida et al., 2012. }\end{array}$ \\
\hline & Bakery business & ITPC, 2018; ABIP, 2018; SEBRAE, 2016; 2017. \\
\hline Strategic entrepreneurship & Resource orchestration & $\begin{array}{l}\text { Hitt et al., 2011; Omotosho \& Anyigba, 2019; } \\
\text { Kantur, 2016; Sirmon et al., } 2011 .\end{array}$ \\
\hline
\end{tabular}

Finally, respecting the ethical principles that guide these studies, the companies will not be identified (Flick, 2018). Insteadwe will use an abbreviation with the letter B followed by an Arabic number to refer to each of the cases.

\subsection{GENERAL SAMPLE ANALYSIS: MICRO AND SMALL COMPANIES AND BAKERY SECTOR}

Micro and small enterprises (MSEs) have a simple and lean organizational design so administrative and operational works tend to merge in a single effort and the same person may execute many tasks, correlated or not (Kelliher \& Reinl, 2009; Darcy et al., 2014). Another inherent characteristic is a more limited resource base and competencies to manage them (Parida et al., 2012; Wrona \& Ladwig, 2015).

In these companies there is a strong dependence on the main administrator, usually the coowner, who centralizes the decision process and, in many occasions, has to act as an expert in almost all management areas without the proper qualifications (Kelliher \& Reinl, 2009; Darcy et al., 2014). Many of the owners do not know the range of their own organizational resources and cannot explore their whole potential (Parida et al., 2012). Thus, on the MSEs, the administrative process tends to follow an intuitive and less analytical form, which can be harmful (Wrona \& Ladwig, 2015).

In Brazil, besides the great impact of these companies on the economy, some sectors are predominantly formed by MSEs (Serviço Brasileiro de Apoio às Micro e Pequenas Empresas [SEBRAE], 2017). This is the case of the bakery sector, in which MSEs consist of $96 \%$ of the participation (SEBRAE, 2016; Associação Brasileira da Indústria de Panificação [ABIP], 2018). The sector is among the six biggest of the Brazilian industry, with revenues of over $\mathrm{R} \$ 90$ billion and is responsible for about 850 thousand direct and over 1.8 million indirect employments (SEBRAE, 2016; 2017; Instituto Tecnológico de Panificação e Confeitaria [ITPC], 2018). 
This study focused on artisanal bakeries, responsible for over $80 \%$ of the national production and whose products go directly to the final consumers (SEBRAE, 2016; ITPC, 2018). According to the predominant business model, these companies can be classified as (i) traditional bakeries, focused on the production of baked items of daily consumption; (ii) in-store bakeries, which,besides traditional items, offer other convenience products; (iii) boutique bakeries, whose focus is the production of special bread and other gourmet products; (iv) foodservice bakeries, that besides traditional and convenience items, offer meal service in-store (ITPC, 2018; ABIP, 2018).

The sector is important for this study due to the changes that have influenced not only the business model of the bakeries but also their operational routines and process technologies necessary to direct their actions in a competitive environment (ITPC, 2018). International tendencies are related to offering a greater assortment of items, and increasing the sophistication of products to increase consumption, including in-store (ITPC, 2018). Likewise, it should be highlighted the increased demand for natural leavening bread, which is healthier and of higher added value (SEBRAE, 2017).

As discussed ahead, some companies have altered their main routines aiming to adapt to new consumption patterns: greater assortment and natural appeal products. This has influenced not only the variation and selective retention of new action patters of the main routines (Pentland et al., 2012) but also the resources orchestration process through acquisition, internal development or different combinations of the available assets to optimize the business outputs as a whole (Wernefelt, 2011; Maritan \& Peteraf, 2011; Sirmon et al., 2011).

The sum of this important dynamic in the bakery sector, with the evidence that it is formed predominantly by small businesses and its relevance for the economy and job creation, as diagnosed by the main entities that deal with the bakery activity in Brazil (ITPC, 2018; ABIP, 2018; SEBRAE, 2016, 2017), make the activity relevant to this study. Even the compatibility of its attributes with the application of the main theoretical constructs that support the research, contemplate the development of the theoretical argument underlying the proposed model.

Before proceeding with the analysis of the cases, it is worth mentioning that belonging to the same sector does not mean that the companies studied are homogeneous. There are differences between each case in regards too the predominant business model, robustness of the administrative infrastructure, and operational routines, among other aspects as highlighted in Table 3.

However, although some peculiarities have emerged during data collection, they do not weaken the theoretical argument or the proposed model. In fact, the particularities of each company when dealing with operational routines and eventual process innovations contributed to making more evident the power of routines as generative systems capable of expanding the accumulated product portfolio, processes, and know-how (Pentland et al., 2012; Feldman et al., 2019), at least in the investigated cases. This will be covered below. 
Table 3

Additional information about the cases

\begin{tabular}{|c|c|c|c|}
\hline Case & Business model & General information & Highlights in operational \\
\hline B1 & Boutique bakery & $\begin{array}{l}3 \text { years in the bakery } \\
\text { sector; } 26 \text { employees; } \\
\text { family business; robust } \\
\text { administrative infrastructure } \\
\text { (management software and } \\
\text { office staff). }\end{array}$ & $\begin{array}{l}\text { Modern equipment and strong use of } \\
\text { process technology (fermentation chamber, } \\
\text { deep freezer, high precision furnaces); } \\
\text { natural fermentation; make-to-stock } \\
\text { manufacturing system; strategic focus on } \\
\text { product and process innovation. }\end{array}$ \\
\hline B2 & Foodservice & $\begin{array}{l}20 \text { years in the bakery } \\
\text { sector; } 40 \text { employees; robust } \\
\text { administrative infrastructure } \\
\text { (management software, office } \\
\text { staff, financial consultant). }\end{array}$ & $\begin{array}{l}\text { Greater automation of the process (tight } \\
\text { coupling of production equipment); high } \\
\text { specialization of production employees; } \\
\text { strategic focus on customer service and } \\
\text { experience. }\end{array}$ \\
\hline B3 & Foodservice & $\begin{array}{l}34 \text { years in the bakery sector } \\
\text { ( } 2 \text { under control of the } 2^{\text {nd }} \\
\text { generation); } 23 \text { employees; } \\
\text { family business; deficient } \\
\text { administrative infrastructure } \\
\text { (implementation phase of } \\
\text { more complete management } \\
\text { control software). }\end{array}$ & $\begin{array}{l}\text { More intuitive production process; } \\
\text { old equipment (being updated); lower } \\
\text { standardization of operational processes; } \\
\text { strategic focus on price competition. }\end{array}$ \\
\hline B4 & Foodservice & $\begin{array}{l}46 \text { years in the bakery sector } \\
\text { ( } 24 \text { under management } \\
\text { by the current owner); } \\
65 \text { employees; robust } \\
\text { administrative infrastructure } \\
\text { (management software, office } \\
\text { staff). }\end{array}$ & $\begin{array}{l}\text { Greater automation of the process (tight } \\
\text { coupling of production equipment); high } \\
\text { specialization of production employees; } \\
\text { strategic focus on customer service and } \\
\text { experience; ample space for creating new } \\
\text { products and changing operational routines }\end{array}$ \\
\hline B5 & Foodservice & $\begin{array}{l}48 \text { years in the bakery sector } \\
\left(8 \text { under control of the } 2^{\text {nd }}\right. \\
\text { generation); } 40 \text { employees; } \\
\text { family business; deficient } \\
\text { administrative infrastructure } \\
\text { (implementation phase of } \\
\text { more complete management } \\
\text { control software). }\end{array}$ & $\begin{array}{l}\text { More intuitive production process; old } \\
\text { equipment (being updated), but tight } \\
\text { coupling of production equipment for } \\
\text { some automation; lower standardization } \\
\text { of operational processes; strategic focus } \\
\text { on competition and customer service; } \\
\text { ample space for creating new products and } \\
\text { changing operational routines. }\end{array}$ \\
\hline B6 & Foodservice & $\begin{array}{l}8 \text { years in the bakery } \\
\text { sector; } 83 \text { employees; } \\
\text { robust administrative } \\
\text { infrastructure (management } \\
\text { software provides real-time } \\
\text { information, office staff); } \\
2 \text { stores and a production } \\
\text { center. }\end{array}$ & $\begin{array}{l}\text { Modern equipment and strong use } \\
\text { of process technology for automation } \\
\text { (fermentation chamber, deep freezer, high } \\
\text { precision furnaces); greater standardization } \\
\text { of operational processes; strong managerial } \\
\text { control; strategic focus on competition by } \\
\text { product and process innovation. }\end{array}$ \\
\hline
\end{tabular}




\section{RESULTS ANALYSIS}

The bakery sector has been through changes due to the increasing demand for natural leavening products and other high added value products for immediate consumption (ITPC, 2018; ABIP, 2018; SEBRAE, 2016, 2017). This has drastically altered not only the main operational routines, but also the business model itself as seen in the studied companies. In order to maintain cohesion about the information relevant to this analysis, each case will be presented in sequence, with only the most significant similarities or differences highlighted in relation to the others. The objective is to build an overview, in an aggregate perspective, of the relationship between the use of process technologies via productive resources or artifacts, driven by the mastery of operational routines, for the diversification of the product portfolio and other services and procedures that add value to the activity of these companies.

B1 is a company specialized in the production of natural leavening bread and fits the boutique bakery model. The business, though already adapted to one of the main tendencies of the sector, has been through changes to suit the foodservice proposal and, thus, also offers immediate consumption items. According to the owner, the strategy is to add value to the main bakery products that are used as inputs on the meal production routines, increasing substantially the outputs of processes of the bakery (Hitt et al., 2011). In other words, the outputs of the routines of the main products become inputs in other routines that add value to the result and business proposal of the company.

Differently from the other bakeries, B1 works with a system of make-to-stock: most of its products are frozen and stored in order tohave the final production stages concluded at a later time. However, this process is only possible due to the inclusion of some equipment such as ultra-freezers, which freezes the bread fast, while avoid the formating of ice crystals that affect the elasticity of the dough; cooling chambers, that keeps the products frozen until the productions require; and fermentation chambers, that control precisely the proper temperature and humidity to keep the quality and uniformity between production batches.

This build-to-stock strategy associated with the said equipment implies more automation on the routine of the company. To produce the first batches of the day, for example, it is not necessary to have an employee: the fermentation chamber is programmed so the products are ready to be baked at a precise time. Nevertheless, there is no rigid production planning: the existence of stocks of items in process makes the operating system of the company more flexible, so that it adjusts itself according to the demand.

Regarding the main resources that give an advantage to B1, the inputs and equipment were reported, which contribute to the quality of the final product, and the store environment. Among the main inputs, imported flour and natural yeast should be highlighted. This is a living yeast of unique flavor that it is the same as has been cultivated since the beginning of the company operations. As for the store environment, it is the result of the company's path and cannot be imitated (Grant, 1991; Rashidirad et al., 2015): the bakery is located on a historic property that belongs to the owners' family; it is not a resource that can be acquired by the competing companies.

Nevertheless, the interviewee claims that resources, alone, are not able to leverage the company's operation; it is the group of assets, operating cohesively that may contribute to a superior result (Grant, 1991; Barney \& Arikan, 2017). Likewise, the learning process through routine exercises, the how-to-do, is fundamental to developing new products and expanding the organization's activities.

At the company B2, the manufacturing process is simpler and an approach based on expected daily demand was chosen, so there are no stocks of the products. The company, which fits on 
the foodservice model, besides meals and traditional baked items, has been making an effort to increase the production of natural leavening bread and, thus, meet this increasing demand (ITPC, 2018). However, differently from the other MSEs, at B2 employees are highly specialized and their abilities are restrictedly applied to each group of products.

Though not using differentiated equipment, B2 has robust management software that allows for the compiling of historic information of demand to generate very precise previsions and define the daily production. Likewise, the expertise of the management team, especially about finances, allows for a rigorous control of cash flow, which relieves part of the pressure given by the strong competition in the sector. Still, the interviewee revealed that there is a tacit partnership between businesspeople in the field, which makes the practice of predatory strategies less probable, which could be damaging for the market.

As for the existence of valuable resources, it should be highlighted the location and administrative infrastructure. This last is highlighted for its contribution to the resources orchestration process and precise execution of production routines (Hitt et al., 2011; Sirmon et al., 2011). According to the interviewee, the way the company balances the use of its resources is what maintains its performance, in other words, the ability to orchestrate the resources becomes more relevant than the resources themselves.

About the innovations on the product portfolio and production processes, at B2 the main influences are fairs of the sector, which show novelties for equipment and tendencies, and partnerships with suppliers. Eventually, specialized technicians are sent to the company to develop new products and train employees. Though the company is able to include new items to its production, developing them is beyond its scope, thus, these partnerships that explore the complementarity of capabilities with its suppliers are the alternative to add value to the result of the organization (Hitt et al., 2011).

This strategy is the same used by company B3: through a partnership with suppliers, new products and production processes are developed. The company, which has over 30 years in the bakery sector, fits the foodservice model and undergoes a series of drastic changes associated with the new management, currently under the responsibility of the founders' children.

In order to optimize its processes and increase production capacity, new types of equipment have been acquired and incorporated into the main routines, profoundly altering them and making the process more automatic. Still, production is based on the expected daily demand, without stocks.

Those many changes, however, are not being followed by the register of new routines: manuals are outdated and it can be seen many variations on the production process seeing better performance. The selection and retention of these alterations are being done gradually, as the benefits for the company and client can be seen (Pentland et al., 2012; Hitt et al., 2011). In this process, knowhow and the production teams expertise have strongly contributed to adding value to the result.

Though the company is not interested in entering natural leavening bread production, the decision to start food services in-store was made before it became a trend: the company was one of the pioneers of the region to adopt the foodservice model. Its tradition in the area where it operates contributes to its recognition among the public and becomes an intangible resource that cannot be replicated (Itami \& Roehl, 1987; Rashidirad et al., 2015).

However, as in other cases, common and accessible resources for competition, such as new equipment and other process technologies, have also been contributing to increasing the company's performance. It is the orchestration of these elements, together with the experience in the sector 
and the company's reputation, that enhances its effects to add value to the organizational action (Sirmon et al., 2011; Omotosho \& Anyigba, 2019).

The experience in the market also makes an invisible active (Itami \& Roehl, 1987) that strongly influences the result of company B4. The bakery, which is on the market for over twenty years, has a robust production infrastructure and, besides traditional bakery products, also offers meals. Though it does not produce natural leavening items, the company offers a more sophisticated line of functional bread, which is also a trend in the sector (ITPC, 2018).

Due to eventual alterations on the original routines, the schemes are outdated. Still, the domain of production process allows it to be replicated by the team without major problems for the quality or uniformity of the products. Employees also strongly contribute to innovation in terms of the diversification of the portfolio. Differently from other cases, at B4 the recipes are developed completely internally, without using the participation of external technicians. However, this does not imply that the company does not develop partnerships: based on the company's mastery of the process of creating and executing recipes, the complementarity of capabilities with suppliers has been explored through the adaptation of some inputs to the company's product innovations (Hitt et al., 2011).

The success of B4, according to its main manager, is due to the company's compromise in aggregating value to the consumer and creating a bigger bond with the community (Hitt et al., 2011). The company has already offered other related services, such as catering, but without losing its essence. The interviewee claims that innovations are not restricted to technological apparatus; they are a way to contact the client's emotion and add value to the company's results regardingother aspects beyond profitability (Omotosho \& Anyigba, 2019).

However, though the focus is on the value aggregated to the community through the services provided, financial performance is essential to maintaining the operations of the bakery. From this perspective, the control of the input's acquisition process and strict routines exercise to avoid waste are essential to maintain financial health.

Lastly, it should be highlighted that, in this company, the great source of learning is the constant review of its production routines in order to adequate its outputs to the consumer's demands. Listening to the client and, especially, the non-client is a singular ability that has contributed to the company innovate in tune with the opportunities and needs of the environment it operates (Kantur, 2016; Omotosho \& Anyigba, 2019). It also contributes to innovation, the participation of the company in fairs and conventions of the sector, and the network with other businesspeople. About this last aspect, the implementation of performed routines in other companies, and that is compatible with the current process at B4, have become a source of innovation.

Routines import are also explored by B5: besides strong participation in events of the sector, operational practices of companies that are considered references in other regions influence its innovation process. In this company, however, there are no registers of the production routines in manuals or operating procedures. It is the ostensive element, settled in the frequent exercise of the processes, that guides routine execution.

B5 fits the foodservice bakery model, however, its manager claims that it did not make the company lose its identity as a bakery. According to him, by incorporating meal services and others of higher aggregated value, many competing companies lose focus on their primary activity, bread production. Still, his company follows a less orthodox alternative to explore the selling of the main product and aggregate further value to the client.

The company has a very wide portfolio of bread and meal services, which was a result of frequent adjustments of the routines of the main production processes. However, besides that, 
B5 offers other, non-correlated, services that add value to its results, such as bill payment and sales of products typical to a grocery store. The businessman claims that this does not represent a loss of focus; according to him, his intention is to offer the maximum of convenience and utility to the client that chooses his bakery.

This is related to the main resource informed by the interviewee: the company's credibility. The focus of the business on bread production attracts clients, however, to aggregate value to the purchasing experience, the structure of a chain of useful services can optimize the consumer's time and is valued by the target public.

The last case, B6, is also a food service type bakery, but stands out for its robust production and administrative infrastructure. The company has two stores and one production plant equipped with modern machinery that contributes to the larger automatization of the processes and uniformity of the products. Furthermore, the management software used provides real-time information and precise reports so the management can take more assertive decisions about the allocation of production resources, aiming to decrease waste. In this sense, production routines whose main inputs are traditional products that lost their freshness were created; routines work as processes able to generate a greater variety of outputs from small variations of the same resource base (Pentland et al., 2012).

The creative process at B6, however, takes place in a more targeted way since, at the operational level, routines are executed rigidly and with few variations. But this does not imply a lack of flexibility: the company has specific employees that eventually work on new products. The manager says that most of his recipes were developed internally but not created by his team. Besides acquiring recipes through consultants, suppliers, and other partners, the company tries to unravel recipes of competing companies' famous products. Analogously to a reverse engineering process, product recipes are gradually calculated and adjusted to be incorporated into B6's portfolio.

This exchange of production processes also arises from visits to reference companies in Brazil and abroad. One example was the change in the routine of one of the main products: after the acquisition of new ovens, the baking process started to be done in-store, increasing the degree of contact between the operation and the client. This process innovation brought almost immediate results for the sale of some items.

Still about this bias, the company is still going through changes in process technology, inputs, and production routines to increase its participation in the natural leavening bread sector. This movement aims to add value to the client and also stand out in relation to boutique bakeries in the region.

The analysis of the cases above allows us to infer that despite the particularities, from an aggregate perspective, the companies studied have a similar dynamic regarding their operational processes. In general, the combination of mastery of their operational routines with technological advances and other process innovations allows them to develop new possibilities to deliver value to customers in the form of products and procedures capable of raising the quality of the service provided. This argument is decisive for the creation of the base of the proposed model since it encompasses the theoretical relationship established between routines, process innovations through automation resources, and organizational learning in all cases.

About the differences, those most critical concern the degree to which each of the companies employs process automation technology in the form of artifacts and other operational resources. These are the variations that complement the previously identified relationship between the main constructs, as they allow us to infer how the gradation in the use of process innovations, as associated with operational expertise, is what defines the intensity of the diversification of the 
portfolio of products and procedures that add value to the service provided. In other words, it is the particularities between the cases that allow us to infer variations in the magnitude of the generation of novelties through routines caused by the contingency aspects of each company's operations.

Based on the presented data and in these inferences, here follows a discussion about the theoretical argument developed based on the relationship between the main constructs underlay the research and presentation of the developed model.

\section{DISCUSSIONS}

The empirical evidence found on the analyzed cases confirms the relation between routines, resources orchestration process and organizational learning, as well as the theoretical assumption of routines as the foundation to capabilities and as generative systems (Hitt et al., 2011; Pentland et al., 2012; Feldman et al., 2016; Deslée \& Ammar, 2016). The understanding of routines as an engine of operational innovation processes in the context analyzed highlights that, even in the case of the more severe restrictions of small businesses, their generative nature produces continuous incremental changes that directly influence how these companies operate to deliver their value proposition (Feldman et al., 2019; Van Mierlo, Loohuis, \& Bandarouk, 2019). Furthermore, the inherently material dimension of routines is also confirmed by the influence of non-human agents, artifacts, in this evolutionary process (Dittrich \& Sield, 2018).

In the search for keeping updated or increase competitive performance, the studied companies have been altering production routines to add value to their results and diversifying their outputs with an entrepreneurial perspective that aims to explore new business possibilities and opportunities (Hitt et al., 2011). Many of these alterations are the result of the know-how accumulated by operational practice and, simultaneously, contribute to organizational learning and the development of superior competencies (Ranucci \& Souder, 2015; Appiah \& Sarpong, 2015; Deslée \& Ammar, 2016).

Such abilities, scattered in the form of routines, have an impact on organizational resources orchestration and, associated to technological apparatus and other process innovations, aggregate value to the outputs and have increase these companies' performance (Prahalad \& Hamel, 1990; Sirmon et al., 2011; Shin et al., 2017). Thus, this research contributes with the evidence that the combination of different sources of resources, innovation, and competences in the development of operational processes, in an accumulated way, are the propellers for action and the generation of novelties, enabling the leverage of operations in a strategic dimension (Van Mierlo et al., 2019).

Another relevant advance that supports the model built in this work is related to the sociomateriality inherent in the routines (Feldman et al., 2019). Even with the limitations of access to credit and productive resources (Wrona \& Ladwig, 2015), in the investigated cases, the enactment of technological artifacts in the performance of routines reveals their proactive role in the evolution of these processes. Although it is not possible to associate conscious deliberation with such artifacts, it is possible to argue that their sense of purpose is built through their involvement in the achievement of operational processes (Dittrich \& Seidl, 2018). The artifacts alter the understanding of human actors about a given routine by enabling new possibilities for action; thus, they amplify the ability to learn, generate novelty, and assume a deeper dimension that transcends their technical and material attributes (Boe-Lillegraven, 2019).

The discussion about the mediating role of artifacts for innovation in small business operational routines is an analysis which is related to this work. The evidence found added to the theoreticalempirical argument formulated from it. Itis essential for the construction of the proposed model 
and represents an advancement in current research. Indeed, recent technological advances and widespread recognition of their potential economic and social effects are providing fertile bases for studying the role of artifacts and the materiality of routines and reveal a gap to be filled by research (Feldman et al., 2019, p .7). Naturally, the scope of these new research possibilities includes the meaning of routines as generative systems adopted in this work, since the artifacts assume a complex dimension and a proactive role in achieving the processes of which they are part of, in a recursive way: they influence and are influenced by the performance of a routine (Boe-Lillegraven, 2019; D’Adderio, 2011).

Going further, the interaction between human actors and artifacts is the key to the development of: reflective spaces, in which new possibilities of action are outlined; and experimental spaces, which give rise to experimentation and performance of new standards (Kiwan \& Lazaric, 2019). This ecology of reflective and experimental spaces produces opportunities to remodel and develop routines in an innovative perspective and amplifies organizational learning and the accumulation of know-how (Kiwan \& Lazaric, 2019; Sele \& Grand, 2016), even in predominantly operational and resource-constrained contexts like the one analyzed in this work.

On an entrepreneurship and, simultaneously, strategic perspective, the studied companies seek to develop in the present time the resources and capabilities that are believed to be necessary to ensure their future performance (Grant, 1991; Itami \& Roehl, 1987; Kantur, 2016).

Thus, it is possible to infer that, over time, the combination of developed competences with other resources and technologies are fundamental to the development of more complex organizational routines (Becker et al., 2005; Matzler et al., 2010; Pentland et al., 2012; Shin et al., 2017). As generative systems are analyzed as a function of time and innovation, routines represent, as a result: outputs and work processes diversification; an increase of the company's expertise; and higher aggregated value to the company and its target public (Ranucci \& Souder, 2015; Deslée \& Ammar, 2016; Hitt et al., 2011; Omotosho \& Anyigba, 2019). The proposed model to comprehend the evolution of routines is shown in Figure 3.

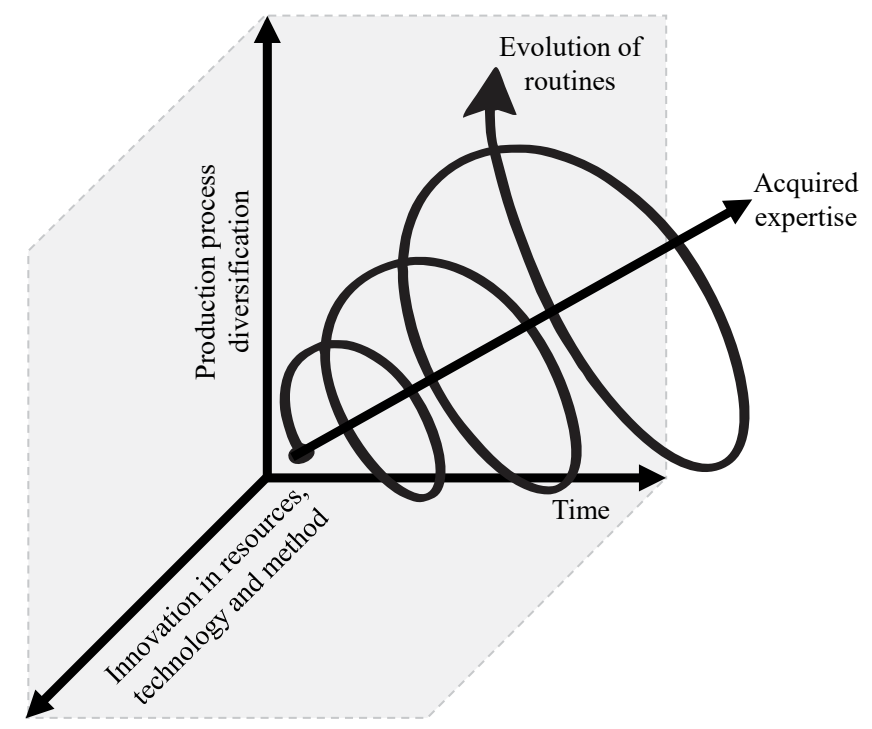

$$
r: A \rightarrow B, r=f(t, i)
$$

Where:

$\mathrm{r}=$ routine;

$\mathrm{t}=$ time;

$\mathrm{i}=$ innovation;

Figure 3. Evolution of developed routines and skills: diversification of processes as a function of time and innovation.

Source: Recovered from "Estudo de rotinas de operações com Business Process Modeling (BPM) para identificar a orientação estratégica em micro e pequenas empresas” of J. C. Costa, Jr., 2019, Masters dissertation, Universidade Federal de Pernambuco, Recife, PE, Brasil, p.37. 
According to a theoretical proposal, the evolution of routines does not conserve a purely linear format. Organizational expertise is progressive and can be abstracted as a cumulative element over a chronological timeline. However, routines are dynamic processes marked by almost permanent conflicts among its ostensive, performative components, and artifacts (Feldman et al., 2016). Thus, on the model, this dynamism underlays the spiral format to conceive oscillations between dynamic balance and change and the consequent diversification of processes represented on the vertical axis.

Furthermore, the spiral format allows us to better comprehend the effect of specific innovations that can be associated with punctual events on the chronological timeline, event time. Thus, an intense and eventual innovation can, in short calendar time, accelerate the evolution of production routines and its potential to the diversification of process, which would be marked by the accession of the spiral on the vertical axis but with a low displacement between the axis of independent variants.

The model also incorporates the recursive relationship between innovation and organizational learning from an intra-organizational perspective. According to the theoretical argument presented, innovations in process, including via artifacts, create new possibilities for action and alter the perception and understanding of human actors about a routine (Dittrich \& Seidl, 2018; BoeLillegraven, 2019). Therefore, the generation of novelties during the performance of a new pattern of actions, in a recursive and incremental manner, also enables new possibilities for innovation, supported by these novelties, which are gradually experimented with and incorporated into the portfolio of routines.

It is noteworthy that, in data collection, evidence emerged that some of the interviewed entrepreneurs, to a greater or lesser degree, are looking for external knowledge that can be combined with the expertise acquired by operational practice to develop new routines. However, at the moment, the focus of the model is on how innovations, over time, imply impacts on routines due to their influence on the resource orchestration process. Naturally, this finding maintains a direct relationship with related theoretical constructs such as absorptive capacities (Cohen \& Levinthal, 1990; Jansen, Van Den Bosch, \& Volberda, 2005; Zahra \& George, 2002) and ecology and interdependence of routines (Kremser et al., 2019; Sele \& Grand, 2016; Feldman et al., 2019). However, this research has a specific focus on operational routines from an intra-organizational perspective and assumes that routines are antecedent to capabilities (Pentland et al., 2012). The insertion of the perspective of interdependence of routines and absorptive capacities, a more comprehensive construct, represents a natural evolution of the proposed model, being included in the research agenda proposed.

Another relevant contribution of this research is that the model was developed based on the analysis of small businesses, a relevant group to the economic development of many developing countries (Eijdenberg et al., 2017), such as in the case of of Brazil. Studies focusing on the management of entrepreneurial actions with an emphasis on the growth of small businesses also refer to a gap in research (Eijdenberg et al., 2017, p.36). In addition, a substantial part of the conceptual tools that seek to explain competitiveness is derived from studies carried out with large organizations in developed countries, which makes questionable findings that do not consider the particular characteristics that affect the way in which small businesses operate (Darcy et al., 2014, p.399).

Therefore, by considering scalability in adapting more comprehensive constructs to the context of small businesses, the model can also help practitioners to develop incremental approaches regarding the application of innovations in the process of orchestrating resources to expand the 
operational limits of these organizations. Even considering the recursive effect observed in regards to small innovations in the operational routines, an emphasis on low-cost increments may be sufficient to leverage the results of these companies.

Lastly, though the study meets its goal of the construction of this model, complementary and supplementary discussions are useful for a broad understanding of the elements that composes it and for its progress, including in an inter-organizational perspective, as suggested ahead.

\section{CLOSING REMARKS}

The analysis and discussion of the results allow inferring that routines are intrinsically related to organizational resources orchestration and the development of competencies on entrepreneurship and strategic perspective (Hitt et al., 2011; Deslée \& Ammar, 2016). Under the entrepreneurship bias, it enables prospecting new alternatives to apply and develop the current resource base to suit the environment and seize opportunities, exploration; as for under the strategic bias, it allows to optimize the use of assets and competencies in the course of the current strategy to ensure return, exploitation (Sirmon et al., 2011).

On a dynamic process, routines performance enables a company to accumulate knowledge and develop intangible assets which are able to increase future competitiveness on a dynamic resource fit (Becker et al., 2005; Itami \& Roehl, 1987). Associated to innovations of process and technologic artifacts, such elements add value to the result and also diversify the possibilities of outputs resulted from the same range of operational processes (Shin et al., 2017).

The model proposed in figure 3, the main contribution of this study, helps comprehend the effect of routines as a generative system and also for the incorporation of new resources and innovations for the organizational processes (Pentland et al., 2012; Kremser et al., 2019; Feldman et al., 2019). Likewise, it also allows visualizing how time and innovation variants are related to the outputs of organizational actions; the evolutions of routines themselves; and organizational learning (Feldman et al., 2016; Bredillet et al., 2018). This work, therefore, represents an incremental advance in research aimed at building models with an emphasis on entrepreneurial actions in small businesses (Eijdenberg et al., 2017, p.36). Similarly, the proposals presented also contribute to studies on the role of technology and innovation on organizational action, with an emphasis on artifacts and the materiality inherent in routines (Feldman et al., 2019, p.7).

In addition to the variables included in the model, additional findings should be highlighted that will allow, based on data collection with an emphasis on interfirm relationships, to explore more comprehensive constructs related to the theme of this research: (i) ecology and interdependence of routines (Feldman et al., 2019); and absorptive capabilities (Cohen \& Levinthal, 1990). The perspective of interdependence between routines is based on the assumption that organizational routines are related to other routines, inside and outside the organization (Feldman et al., 2019; Boe-Lillegraven, 2019). Exploring how punctual innovations in specific organizational routines can reverberate into the meta routines is a feasible way to produce inferences about a broader construct, capabilities (Pentland et al., 2012; Bredillet et al., 2018). On another path, exploring how innovations in the routines of business partners and customers reverberate in the processes of an organization, will allow us to understand the influence of these relationships for organizational learning and adding value to the operational result (Kremser et al., 2019).

With this perspective, when analyzing the mechanism of these routines that incorporate external knowledge to the organization in the learning process, a bridge will be created for a macro level of analysis that will allow conclusions about the absorptive capacity, that is, the ability of a company to recognize the value of external knowledge, assimilate it and apply it to your processes 
BBR

18

510

(Cohen \& Levinthal, 1990, p.128). Both the potential dimension, about the acquisition and assimilation of external knowledge, and the realized dimension, about the transformation and exploration of this knowledge (Jansen et al., 2005; Zahra \& George, 2002), can be analyzed based on clusters of specific routines that deal with the interface between the company and the external environment (Kremser et al., 2019). Other useful paths to amplify the debate are targeted at the research agenda proposed in Table 4.

Table 4

Future research agenda

\begin{tabular}{|c|c|c|}
\hline Research topic & Possible ways of analysis & Correlated references \\
\hline Strategic orientation & $\begin{array}{l}\text { Operational routines and their relation to } \\
\text { strategic action in SME context }\end{array}$ & $\begin{array}{l}\text { Cadogan (2012); Laukkanen et al. } \\
\text { (2013); Costa (2019). }\end{array}$ \\
\hline $\begin{array}{l}\text { Innovation through } \\
\text { routines }\end{array}$ & $\begin{array}{l}\text { Practice theory, emphasis on the } \\
\text { relationship between action and structure }\end{array}$ & $\begin{array}{l}\text { Blanche \& Cohendent (2019); Van } \\
\text { Mierlo et al. (2019); Sonenshein } \\
\text { (2016). }\end{array}$ \\
\hline $\begin{array}{l}\text { Interdependence of } \\
\text { routines in the border of } \\
\text { organization }\end{array}$ & $\begin{array}{l}\text { Routines and their relation to other } \\
\text { routines in the border of organization and } \\
\text { transfer routines }\end{array}$ & $\begin{array}{l}\text { Kremser et al. (2019); Sele and } \\
\text { Grand (2016). }\end{array}$ \\
\hline $\begin{array}{l}\text { Artifacts and } \\
\text { sociomateriality }\end{array}$ & $\begin{array}{l}\text { The effect of technological artifacts on the } \\
\text { understanding of human actants about } \\
\text { the logical aspect of routines (ostensive) } \\
\text { and its performativity }\end{array}$ & $\begin{array}{l}\text { Kiwan \& Lazaric (2019); Kho et al. } \\
\text { (2019); D’Adderio (2011, 2017); } \\
\text { Orlikowski (2015); Dittrich \& Sield, } \\
\text { (2018). }\end{array}$ \\
\hline $\begin{array}{l}\text { Complementarity of } \\
\text { routines }\end{array}$ & $\begin{array}{l}\text { The effect of interdependence of routines } \\
\text { to add value to the organizational action } \\
\text { in a business relationship and generation } \\
\text { of wealth. }\end{array}$ & $\begin{array}{l}\text { Omotosho \& Anyigba (2019); Hitt } \\
\text { et al. (2011); Dias et al. (2019). }\end{array}$ \\
\hline $\begin{array}{l}\text { Routines and resource } \\
\text { management }\end{array}$ & $\begin{array}{l}\text { Operational routines control and their } \\
\text { effects resource orchestration }\end{array}$ & $\begin{array}{l}\text { Hitt et al. (2011); Omotosho \& } \\
\text { Anyigba (2019); Bredillet et al. } \\
\text { (2018); Deslee \& Ammar (2016). }\end{array}$ \\
\hline Transfer of routines & $\begin{array}{l}\text { Process of replication and transfer of } \\
\text { routines in the case of competitors } \\
\text { organizations in the same sector }\end{array}$ & $\begin{array}{l}\text { Blanche \& Cohendet (2019); } \\
\text { Boe-Lillegraven (2019); } \\
\text { Schmidt et al. (2019). }\end{array}$ \\
\hline Routines and capabilities & $\begin{array}{l}\text { Routines, meta routines and the transition } \\
\text { of bundles of routines to the capabilities } \\
\text { in a macro level of analysis }\end{array}$ & $\begin{array}{l}\text { Kremser et al. (2019); Sonenshein } \\
\text { (2016). }\end{array}$ \\
\hline $\begin{array}{l}\text { Absorptive capacity and } \\
\text { routines }\end{array}$ & $\begin{array}{l}\text { The role of routines for the acquisition } \\
\text { and assimilation of external knowledge } \\
\text { (potential absorptive capacity) and } \\
\text { transformation and exploitation of } \\
\text { resources (realized absorptive capacity) }\end{array}$ & $\begin{array}{l}\text { Cohen \& Levinthal (1990); Jansen } \\
\text { et al., (2005); Zahra \& George } \\
(2003) \text {. }\end{array}$ \\
\hline
\end{tabular}

In addition, future research may also include quantitative or hybrid methods, as a means of legitimate the model and ratify its conclusions. Applying the proposal to other productive sectors and organization sizes would also be relevant to confirm its explanatory power and to obtain incremental contributions. Lastly, longitudinal studies which follow aspects of organizational trajectory, such as the progressive evolution of routines and resource base may reinforce the path dependence perspective and allow greater inferences about events based on the lessons learned in changing the level of analysis from the micro, centered in the routines, to the macro, with focus on capabilities (Pentland et al., 2012). 


\section{REFERENCES}

Associação Brasileira da Indústria de Panificação e Confeitaria. (2018). Balanço e tendências do mercado de panificação e confeitaria. Recuperado em 07 dezembro, 2019, de: http://www.abip.org.br/site/ wp-content/uploads/2018/03/INDICADORES-E-TENDENCIAS-DE-MERCADO.pdf

Appiah, G., \& Sarpong, D. (2015). On the influence of organisational routines on strategic foresight. Foresight, 17(5), 512-527.

Araujo, L., \& Easton, G. (2012). Temporality in business network: the role of narratives and management Technologies. Industrial Marketing Management, 41, 312-318.

Bardin, L. (2016). Análise de Conteúdo. São Paulo, SP: Edições 70.

Barney, J. B., \& Arikan, A. M. (2017). The resource-based view: origins and implications. In: A. Hitt, R. E. Freeman, \& J. S. Harrison (Eds). The Blackwell Handbook of Strategic Management (cap.5, pp.123-182). Blackwell Publishing, 2017.

Becker, M. C., Lazaric, N., Nelson, R. R., \& Winter, S. G. (2005). Applying organizational routines in understanding organizational change. Industrial and Corporate Change, 14(5), 775-791.

Blanche, C., \& Cohendet, P. (2019). Remounting a ballet in a different context: a complementary understanding of routines transfer theories. In: M. S. Feldman, L. D’Adderio, K. Dittrich, \& P. Jarzabkowski (Eds). Routine dynamics in action: replication and transformation (Research in the sociology of organizations, vol. 61) (chap. 1, pp. 11-30). Emerald Publishing Limited.

Boe-Lillegraven, S. (2019). Transfering routines across multiple boundaries: a flexible approach. In: M. S. Feldman, L. D’Adderio, K. Dittrich, \& P. Jarzabkowski (Eds). Routine dynamics in action: replication and transformation (Research in the sociology of organizations, vol. 61) (chap. 2, pp. 3151). Emerald Publishing Limited.

Bredillet, C., Tywoniak, S., \& Tootoonchy, M. (2018). Exploring the dynamics of Project management office and portfolio management co-evolution: a routine lens. International Journal of Project Management, 36(1), 27-42.

Brown, R. B., \& Herring, R. (1998). The circles of time: an exploratory study in measuring temporal perceptions within organizations. Journal of Management Psychology, 13(8), 580-602.

Cadogan, J. W. (2012). International marketing, strategic orientations and business success: reflections on the path ahead. International Marketing Review, 29(4), p. 340-348.

Cohen, W. L., \& Levinthal, D. A. (1990). Absorptive Capacity: a new perspective on learning and innovation. Administrative Science Quarterly, 35(1), 128-152.

Costa, J. C., Jr. (2019). Estudo de rotinas de operaçôes com Business Process Modeling (BPM) para identificar a orientação estratégica em micro e pequenas empresas. Dissertação de mestrado, Universidade Federal de Pernambuco, Recife, PE, Brasil.

Creswell, J. W., \& Creswell, J. D. (2017). Research Design: qualitative, quantitative and mixed methods approaches (5th ed.). Thousand Oaks, CA: Sage.

D'Adderio, L. (2008). The performativity of routines: theorizing the influence of artefacts and distributed agencies on routines dynamics. Research Policy, 37(5), 769-789.

D'Adderio, L. (2011). Artifacts at the centre of routines: performing the material turn in routines theory. Journal of Institutional Economics, 7(2), 197-230. 
BBR

18

D'Adderio, L. (2017). Performativity and the innovation-replication dilemma. In: H. Bathelt, P. Cohendet, S. Henn, \& L. Simon (Eds.). The Elgar companion to innovation and knowledge creation (chap. 34, pp. 556-569). Cheltenham: Edward Elgar.

Darcy, C., Hill, J., McCabe, T. J., \& McGovern, P. (2014). A consideration of organizational sustainability in the SME context. European Journal of Training and Development, 38(5), 398-414.

Deslée, C., \& Ammar, O. (2016). Transforming SNCF's business model through the evolution of participative innovation routine. European Business Review, 28(4), 467-485.

Dierickx, I., \& Cool, K. (1989). Asset stock acumulation and sustainability of competitive advantage. Management Science, 35(12), 1504-1511.

Dittrich, K., \& Seidl, D. (2018). Emerging intentionality in routine dynamics: a pragmatist view. Academy of Management Journal, 61(1), 111-138.

Dias, C. N., Hoffmann, V. E., \& Martínez-Fernández, M. T. (2019). Resource complementarities in R\&D network for innovation performance: evidence from the agricultural sector in Brazil and Spain. International Food and Agribusiness Management Review, 22(2), 193-213.

Eijdenberg, E. L., Paas, L. J, \& Masurel, E. (2017). Decision-making and small business growth in Burundi. Journal of Entrepreneurship in Emerging Economies, 9(1), 35-64.

Eisenhardt, K. M. (1989). Building theories from case study research. The Academy of Management Review, 14(4), 532-550.

Eisenhardt, K. M., \& Martin, J. A. (2000). Dynamic Capabilities: What are they? Strategic Management Journal, 21(10), 1105-1121.

Eisenhardt, K. M., \& Graebner, M. E. (2007). Theory building from cases: opportunities and chalenges. Academy of Management Journal, 50(1), 25-32.

Erlingsson, C., \& Brysiewicz, P. (2017). A hands-on guide to doing content analysis. African Journal of Emergency Medicine, 7, 93-99.

Feldman, M. S., D’Adderio, L., Dittrich, K, \& Jarzabkowski, P. (2019). Introduction: routines dynamics in action. In: _. Routine dynamics in action: replication and transformation (Research in the sociology of organizations, vol. 61) (introduction, pp. 1-10). Emerald Publishing Limited.

Feldman, M. S, \& Pentland, B. T. (2003). Reconceptualizing organizational routines as a source of flexibility and change. Administrative Science Quarterly, 48, 94-118.

Feldman, M. S, Pentland, B. T, D’Adderio, L., \& Lazaric, N. (2016). Beyond routines as things: introduction to the special issue on routine dynamics. Organization Science, 27(3), 505-513.

Flick, U. (2018). An introduction to qualitative research (6th ed.). London, UK: Sage.

Grant, R. M. (1991). The resource based theory of competitive advantage: Implications for strategy formulation. California Management Review, 33(3), 114-135.

Hitt, M. A., Ireland, D., Sirmon, D. G., \& Trahms, C. A. (2011). Strategic entrepreneurship: creating value for individuals, organizations, and society. Academy of Management Perspectives, 25(2), 57-75.

Instituto Tecnológico de Panificação e Confeitaria. (2018). Projeção de desempenho das panificadoras e confeitarias brasileiras em 2017. Recuperado em 07 dezembro, 2019, de: http://institutoitpc.org. br/indicadores-do-setor/

Itami, H., \& Roehl, T. W. (1987). Mobilizing invisible assets. Cambridge: Harvard University Press. 
Jansen, J. J. P., Van Den Bosch, F. A. J., \& Volberda, H. W. (2005). Managing potential and realized absorptive capacity: how do organizational antecedents matter? Academy of Management Journal, 48(6), 999-1015.

Kantur, D. (2016). Strategic entrepreneurship: mediating the entrepreneurial orientation-performance link. Management Decision, 54(1), 24-43.

Kellinher, F., \& Reinl, L. (2009). A resource-based view of micro-firm management practice. Journal of Small Business and Enterprise Development, 16(3), 521-532.

Kho, J., Spee, A. P., \& Gillespie, N. (2019). Enacting relational expertise to change professional routines in technology-mediated service settings. In: M. S. Feldman, L. D’Adderio, K. Dittrich, \& P. Jarzabkowski (Eds). Routine dynamics in action: replication and transformation (Research in the sociology of organizations, vol. 61) (chap. 9, pp. 191-213). Emerald Publishing Limited.

Kiwan, L., \& Lazaric, N. (2019). Learning a new ecology of space and looking for new routines: experimenting robotics in a surgical team. In: M. S. Feldman, L. D’Adderio, K. Dittrich, \& P. Jarzabkowski (Eds). Routine dynamics in action: replication and transformation (Research in the sociology of organizations, vol. 61) (chap. 8, pp. 173-189). Emerald Publishing Limited.

Kremser, W., Pentland, B. T., \& Brunswicker, S. (2019). Interdependence within and between routines: a performative perspective. M. S. Feldman, L. D’Adderio, K. Dittrich, \& P. Jarzabkowski (Eds). Routine dynamics in action: replication and transformation (Research in the sociology of organizations, vol. 61) (chap. 4, pp. 79-98). Emerald Publishing Limited.

Laukkanen, T., Nagy, G., Hirvonen, S., Reijonem, H., \& Pasanen, M. (2013). The interaction between environment and strategic orientation in born globals' choice of entry mode. International Marketing Review, 30(6), p. 538-558.

Lindgreen, A., Di Benedetto, C. A., \& Beverland, M. B. (2020). How to write up case-study methodology sections. Industrial Marketing Management, doi: 10.1016/j.indmarman.2020.04.012

Maritan, C. A., \& Peteraf, M. A. (2011). Building a bridge between resource acquisition and resource accumulation. Journal of Management, 37(5), 1374-1389.

Matzler, K., Bailom, F., Anschober, M., \& Richardson, S. (2010). Sustaining corporate success: what drives the top performers?. Journal of Business Strategy, 31(5), 4-13.

Nascimento, L. S., \& Steinbruch, F. K. (2019). “The interviews were trasncribed”, but how? Reflections on management research. RAUSP Management Journal, 54(4), 413-429.

Omotosho, S. I., \& Anyigba, H. (2019). Conceptualising corporate entrepreneurial strategy: a contingency and agency collaborative approach. Journal of Strategy and Management, 12(2), 256-274.

Orlikowski, W. J. (2015). Practice in research: phenomenon, perspective and philosophy. In: G. Golsorkhi, L. Rouleau, D. Seidl, \& E. Vaara (Eds.). The Cambridge Handbook on Strategy as Practice (chap. 1, pp. 23-33). Cambridge, UK: Cambridge University Press.

Parida, V., Westerberg, M., \& Frishammar, J. (2012). Inbound open innovation activities in hightech SMEs: the impacto on innovation performance. Journal of Small Business Management, $50(2)$, 283-309.

Pentland, B. T., \& Feldman, M. S. (2005). Organizational routines as a unit of analysis. Industrial and Corporate Change, 14(5), 793-815.

Pentland, B. T., Feldman, M. S., Becker, M. C., \& Liu, P. (2012). Dynamics of organizational routines: a generative model. Journal of Management Studies, 49(8), 1484-1508. 
Penrose, E. T. (1959). The theory of the growth of the firm. New York: John Wiley, 1959.

Peteraf, M. A., Stefano, G., \& Verona, G. (2013). The elephant in the room of dynamic capabilities: bringing two diverging conversations together. Strategic Management Journal, 34, 1389-1410.

Prahalad, C. K., \& Hamel, G. (1990). The core competence of the Corporation. Harvard Business Review, 68, 79-91.

Ranucci, R. A., \& Souder, D. (2015). Facilitating tacit knowledge transfer: routine compatibility, trustworthiness, and integration in M \& As. Journal of Knowledge Management, 19(2), 257-276.

Rashidirad, M., Soltani, E., Salimian, H., \& Liao, Y. (2015). The applicability of Grant's framework in the dynamic digital age: a review and agenda for future research. European Business Review, 27(6), 656-678.

Rumelt, R. P. Toward a strategic theory of the firm. In: . Competitive Strategic Management. New Jersey: Prentence Hall, 1984.

Schmidt, T., Braun, T., \& Sydow, J. (2019). Copying routines for new venture creation: how replication can support entrepreneurial innovation. In: M. S. Feldman, L. D’Adderio, K. Dittrich, \& P. Jarzabkowski (Eds). Routine dynamics in action: replication and transformation (Research in the sociology of organizations, vol. 61) (chap. 3, pp. 55-78). Emerald Publishing Limited.

Sele, K., \& Grand, S. (2016). Unpacking the dynamics of ecologies of routines: mediators and their generative effects in routine interactions. Organization Science, 27, 722-738.

Serviço Brasileiro de Apoio às Micro e Pequenas Empresas. (2016). Minha Empresa Sustentável: Padaria. Cuiabá, MT: Autor.

Serviço Brasileiro de Apoio às Micro e Pequenas Empresas. (2017). Estudo de Mercado Indústria: Panificação. Salvador, BA: Autor.

Shin, S. R., Han, J., Marhold, K., \& Kang, J. (2017). Reconfiguring the firm's core technological portfolio through open innovation: focusing on technological M \& A. Journal of Knowledge Management, 21(3), 571-591.

Sirmon, D. G., Hitt, M. A., Ireland, R. D., \& Gilbert, B. A. (2011). Resource orchestration to create competitive advantage: breadth, depth and life cycle effects. Journal of Management, 37(5), 1390-1412.

Sonenshein, S. (2016). Routines and creativity: from dualism to duality. Organization Science, 27, 759-781.

Teece, D. J., Pisano, G., \& Shuen, A. (1997). Dynamic Capabilities and Strategy Management. Strategic Management Journal, 18(7), 509-533.

Tracy, S. J. (2010). Qualitative quality: eight "big-tent" criteria for excellent qualitative research. Qualitative Inquiry, 16(10), 837-851.

Van de Ven, A. H., \& Poole, M. S. (1995). Explaining development and change in organizations. Academy of Management Review, 20(3), 510-540.

Van Mierlo, J., Loohuis, R., \& Bondarouk, T. (2019). Remounting a ballet in a different context: a complementary understanding of routines transfer theories. In: M. S. Feldman, L. D’Adderio, K. Dittrich, \& P. Jarzabkowski (Eds). Routine dynamics in action: replication and transformation (Research in the sociology of organizations, vol. 61) (chap. 7, pp. 153-172). Emerald Publishing Limited. 
Wang, Y., \& Wang, K. Y. (2017). How do firms tackle strategic change? A theoretical model of the choice between dynamic capability-based and ad hoc problem-solving approaches. Journal of Organizational Change Management, 30(5), 725-743.

Wernefelt, B. (1984). A resource-based view of the firm. Strategic Management Journal, 5(2), 171-180.

Wernefelt, B. (2011). The use of resources in resource acquisition. Journal of Management, 37(5), $1369-1373$.

Wrona, T., \& Ladwig, T. (2015). Studying strategy formation in small companies - a cognitive perspective. Journal of Strategy and Management, 8(1), 2-22.

Wu, S. J., Melnyk, S. A., \& Swink, M. (2012). An empirical investigation of the combinatorial nature of operational practices and operational capabilities: compensatory or additive?. International Journal of Operations \& Production Management, 32(2), 121-155.

Yin, R. K. (2018). Case study research and aplications: design and methods (6th ed.). Thousand Oaks, CA: Sage.

Zahra, S. A., \& George, G. (2002). Absorptive capacity: a review, reconceptualization, and extension. Academy of Management Review, 27(2), 185-203.

\section{CONFLICTS OF INTEREST}

The authors declare that there are no conflict of interest related to this work.

\section{AUTHOR'S CONTRIBUTION}

All authors contributed equally to the elaboration of the article. 